\title{
Pengaruh Model Pembelajaran PBL terhadap Hasil Belajar Senam Lantai Ditinjau dari Minat Belajar Peserta Didik
}

\section{Ni Wyn Nonik Asriningsih ${ }^{1 *}$, I Wyn Sujana ${ }^{2}$, I Gst Ayu Putu Sri Darmawati ${ }^{3}$}

\author{
1,2,3 Universitas Pendidikan Ganesha, Singaraja, Indonesia
}

\section{A R T I C L E I N F O}

Article history:

Received April 03, 2021

Revised April 15, 2021

Accepted May 02, 2021

Available online August 25, 2021

Kata Kunci

PBL, Minat Belajar, Hasil Belajar

Keywords:

$P B L$, Interest In Learning,

Learning Outcomes

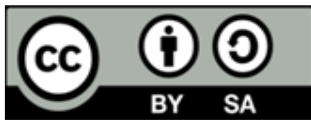

This is an open access article under the CC BY-SA license.

Copyright () 2021 by Author. Published by Universitas Pendidikan Ganesha.

\begin{abstract}
A B S T R A K
Peserta didik mengalami kesulitan dalam melakukan senam lantai. Hal ini disebabkan proses pembelajaran senam lantai masih terpusat pada guru dan rendahnya aktivitas siswa untuk belajar. Tujuan penelitian ini adalah untuk menganalisis model pembelajaran ditinjau dari minat belajar terhadap hasil belajar senam lantai peserta didik kelas V SD. Rancangan penelitian quasi experimental ini dilakukan dengan pendekatan "treatment by level" dengan desain faktorial $2 \times 2$. Subjek penelitian berjumlah 40 orang yang terbagi dalam 2 kelompok, minat belajar tinggi dan minat belajar rendah. Metode pengumpulan data menggunakan kuesioner. Data dianalisis menggunakan analisis deskriptif dan analisis kovarian (ANCOVA. Hasil analisis data penelitian menunjukkan peserta didik dengan minat belajar tinggi, yang menggunakan model pembelajaran PBL mempunyai hasil belajar senam lantai lebih baik daripada yang menggunakan model pembelajaran konvensional. Dapat disimpulkan bahwa model pembelajaran PBL dapat meningkatkan hasil belajar siswa. Implikasi penelitian ini berdampak pada terciptanya suasana belajar yang menyenangkan, sehingga dapat meningkatkan minat belajar dan berpengaruh pada hasil belajar.
\end{abstract}

\section{A B S T R A C T}

Students have difficulty in doing floor exercise, this is because the learning process for floor exercise is still centered on the teacher's learning and the low activity of students to learn. The purpose of this study was to analyze the learning model in terms of interest in learning to the learning outcomes of floor gymnastics for fifth grade elementary school students. This quasi-experimental research design was carried out with a "treatment by level" approach with a 2 × 2 factorial design. The research subjects were 40 people who were divided into 2 groups, high interest in learning and low interest in learning. Methods of data collection using a questionnaire. The data were analyzed using descriptive analysis and covariance analysis (ANCOVA. The results of the research data analysis showed that students with high learning interest, who used the PBL learning model, had better floor gymnastics learning outcomes than those using the conventional learning model. It can be concluded that the PBL learning model can improve student learning outcomes The implications of this research have an impact on the creation of a pleasant learning atmosphere so that it can increase interest in learning so that it affects learning outcomes that increase.

\section{PENDAHULUAN}

Pendidikan menjadi salah satu upaya untuk membangun dan meningkatkan mutu sumber daya manusia menuju era globalisasi yang penuh dengan tantangan, sehingga didasari bahwa pendidikan merupakan sesuatu yang sangat fundamental bagi setiap individu (Dakabesi et al., 2019; Kaban et al., 2021; Maman \& Rajab, 2016). Oleh karena itu, kegiatan pendidikan sangat penting untuk mengembangakan potensi siswa dalam tiga ranah perkembangan yaitu perkembangan kognitif, afekti,f dan psikomotor (Khoiruzzadim et al., 2020; Masithoh, 2018). Salah satu kegiatan untuk pengembangan kemampuan tersebut yaitu kegiatan senam lantai. Senam lantai merupakan salah satu rumpun senam yang berfokus pada gerakan di lantai. Lantai atau matras menjadi alat utama yang digunakan dalam senam lantai (Muhajir, 2014: 197). Materi senam lantai ini telah diberikan pada tingkat sekolah dasar yang menjadi materi pada mata pelajaran Pendidikan Jasmani, Olahraga, dan Kesehatan (PJOK) (Hidayat, 2017; Wicaksono et al., 2020). Materi senam lantai dalam kurikulum mata pelajaran PJOK yang mencakup 
berbagai gerakan dasar. Materi tersebut diharapkan dapat memengaruhi perkembangan psikomotor peserta didik secara keseluruhan, mulai morfofungsional, motorik, psikologis, sampai musikal.

Terdapat hubungan yang kuat antara keterampilan senam, kebugaran, dan peningkatan kemampuan motorik dalam melakukan senam (Halilaj et al., 2018; I. D. Prasetyo \& Sunarti, 2016). Keberhasilan peserta didik menguasai gerakan senam lantai dapat dilihat berdasarkan hasil belajar senam lantai. Hasil belajar merupakan produk evaluasi dari penampilan siswa selama mengikuti pembelajaran pendidikan jasmani dan olahraga di sekolah. Siswa menunjukkan usaha dan kemampuannya baik secara kognitif, afektif, dan psikomotor selama pembelajaran (I. D. Prasetyo \& Sunarti, 2016; Wicaksono et al., 2020). Hasil belajar gerak siswa tidak terlepas dari pengaruh keterampilan motorik salah satunya (Wahyudi \& Hartati, 2015). Selain itu, hasil belajar sangat dipengaruhi oleh minat belajar siswa (Laksono et al., 2016; Rosalina \& Junaidi, 2020; Steven RTerrell Ph D, 2014). Pada pendidikan jasmani dan olahraga, siswa berkesempatan untuk memahami kondisi aktual diri siswa sendiri secara fisik, mental, sosial, dan keterampilan gerak sebagai potensi yang dapat dibina dan dikembangkan untuk menunjang kehidupannya di masa yang akan datang (Mashud, 2020). Peran guru dan orang tua sangatlah penting dalam proses pendidikan agar siswa dapat mengoptimalkan potensi yang dimilikinya (Syahrul \& Nurhafizah, 2021; Wisnu Budi Wijaya, 2019).

Namun kenyataannya, permasalahan umum yang dialami oleh siswa pada saat proses pembelajaran senam lantai masih terpusatnya pembelajaran pada guru, siswa masih belajar secara individu, rendahnya aktivitas siswa untuk belajar, dan model pembelajaran masih bersifat konvensional (Lengo \& Djam, 2019; Lestari, 2013). Permasalahan ini juga terjadi di sekolah lain. Berdasarkan hasil observasi di SDN 3 Kampung Baru, ditemukan bahwa sebagian besar peserta didik kelas V menganggap aktivitas senam lantai merupakan olahraga yang sulit. Peserta didik mengalami kesulitan melakukan senam lantai. Selain itu, kemampuan peserta didik melakukan gerakan berguling ke depan dan berguling ke belakang belum sesuai yang diharapkan. Peserta didik cenderung takut dan tidak percaya diri untuk melakukan gerakan senam lantai. Hal tersebut berdampak pada peserta didik. Mereka sering mengeluh nyeri leher, merasa pusing, dan berkunang-kunang setelah melakukan gerakan-gerakan pada senam lantai. Penyebab kesulitan peserta didik melakukan gerakan pada senam lantai, yaitu peserta didik melakukan gerakan yang tidak sesuai dengan teknik dasar. Permasalahan tersebut jika dibiarkan akan memberikan dampak buruk bagi hasil belajar siswa. Selain itu, tujuan pembelajaran tidak tercapai dengan maksimal.

Berdasarkan hal tersebut dibutuhkan pembelajaran senam lantai yang tepat kepada peserta didik. Proses pembelajaran yang baik dapat meningkatkan dan mengembangkan kebugaran jasmani, kerjasama, keterampilan, dan sikap bersaing yang sangat penting sebagai nilai-nilai yang harus ditanamkan (Bukhari et al., 2019; Stephani, 2017). Salah satu solusi yang dapat dilakukan agar aktivitas dan hasil belajar dapat meningkat yaitu dengan menggunakan model pembelajaran. Model pembelajaran merupakan pembelajaran yang melibatkan siswa untuk bekerja secara aktif untuk mencapai tujuan bersama (Rahmayani et al., 2019; Wahyudi \& Hartati, 2015). Model pembelajaran akan memberikan siswa kesempatan yang lebih banyak untuk melakukan aktivitas yang menyenangkan melalui bentuk interaksi dan kerjasama, seperti melakukan penemuan yang dilakukan dengan percobaan, sehingga kegiatan siswa cenderung untuk mencari tahu tentang prinsip konsep pengetahuan, bukan menunggu diberikan oleh guru (Diah Purwati et al., 2019; Indra et al., 2021; Widoretno \& Dwiastuti, 2019).

Salah satu model pembelajaran yang dapat diterapkan yaitu model pembelajaran problem based learning (PBL). Model pembelajaran PBL merupakan strategi pembelajaran terbaik untuk meningkatkan keterampilan berpikir kritis dan didukung oleh bukti dari studi yang empiris/ilmiah (A.Montepara et al., 2021; Cahyo et al., 2018; Hussin et al., 2018; Misla \& Mawardi, 2020). PBL pada hakikatnya adalah menyajikan kepada peserta didik situasi masalah yang autentik dan bermakna yang dapat memberikan kemudahan kepada mereka untuk melakukan penyelidikan dan inquiri (Saraswatha et al., 2016; Wardani, 2018). Dalam model pembelajaran PBL, peserta didik cenderung menggunakan kecerdasan intelektual atau pola berpikir ilmiah. Model pembelajaran ini juga dapat dipengaruhi oleh keaktifan peserta didik yang ditunjukkan berdasarkan minat belajar peserta didik. Semakin kuat atau dekat hubungan tersebut, maka semakin meningkat minat yang dimiliki (Awe \& Benge, 2017; Nuryanto \& Resita, 2019). Minat belajar dalam proses pembelajaran dapat meningkatkan perhatian, konsentrasi, dan menurunkan kebosanan peserta didik dalam proses pembelajaran, sehingga memperkuat pemahaman mengenai suatu materi. Peserta didik yang mempunyai minat tinggi dalam belajar, maka peserta didik dapat mempelajari materi tersebut yang dilakukan secara sungguh-sungguh, sehingga dapat menurunkan kesulitan dalam proses pembelajaran yang dihadapi peserta didik (Wati \& Muhsin, 2019: 801).

Temuan penelitian sebelumnya yang menyatakan model pembelajaran PBL memberikan pengaruh positif terhadap hasil belajar siswa (Afifah et al., 2019; Kristiana \& Radia, 2021; I. B. Prasetyo, 2018). Model pembelajaran PBL dengan lembar kerja peserta didik dapat membantu meningkatkan 
aktivitas dan hasil belajar peserta didik (Rani \& Syukur, 2019). Model PBL berbasis eksperimen berpengaruh signifikan terhadap hasil belajar kognitif dan afektif siswa (Khoiri et al., 2020). Kemampuan berpikir kritis siswa kelompok Project Based Learning lebih tinggi dibandingkan rata-rata kemampuan berpikir kritis siswa kelompok konvensional (Saputro \& Rayahu, 2020). Rata-rata pemahaman konsep pada calon guru kimia setelah diajar menggunakan model PBL dengan kategori kurang (Sartika, 2018). Penelitian yang dilakukan memiliki keterbaharuan yaitu dengan menerapkan model pembelajaran PBL pada pembelajaran senam lantai. Kajian ini juga belum pernah dilakukan pada penelitian sebelumnya. Tujuan penelitian ini yaitu menganalisis pengaruh model pembelajaran PBL terhadap hasil belajar senam lantai ditinjau dari minat belajar peserta didik. Adanya penelitian ini diharapkan dapat meningkatkan hasil belajar siswa serta minat belajar siswa, khususnya dalam materi senam lantai.

\section{METODE}

Jenis penelitian ini merupakan quasi eksperimental yang dilakukan dengan rancangan "treatment by level" dengan dua kategori 2 x 2. Penelitian ini dilakukan pada 40 orang peserta didik kelas V SDN 3 Kampung Baru, yang terbagi dalam dua (2) kelompok, kelompok minat belajar tinggi dan kelompok minat belajar rendah. Prosedur penelitian ini dilakukan dengan menerapkan protokol physical distancing karena penelitian dilakukan pada masa pandemi Corona Virus Disease - 2019 (COVID-19). Pertemuan dalam penelitian ini dilakukan dengan menggunakan jadwal yang diatur baik kelompok eksperimen dan kelompok kontrol. Peserta didik juga diarahkan untuk menerapkan protokol kesehatan 3M, meliputi mencuci tangan, memakai masker, dan menjaga jarak sejauh 2 meter kepada sesama peserta didik. Instrumen yang digunakan dalam penelitian ini, diantaranya: 1) Kuesioner data demografi, terdiri dari usia, jenis kelamin, dan lama dalam belajar senam lantai; 2) Kuesioner Minat Belajar dari Study Interest Questionnaire (SIQ) yang disesuaikan dengan karakteristik peserta didik. Kursioner ini mengukur minat belajar peserta didik dengan menggunakan tiga indikator, yaitu perasaan terhadap belajar, nilai terhadap belajar, dan orientasi diri (Schiefele, 1999). Kuesioner ini terdiri dari 18 item pernyataan berskala likert, dari skala 1 (sangat tidak setuju) sampai skala 4 (sangat setuju) yang disesuaikan dengan pembelajaran senam lantai. Kuesioner ini terdapat 7 item pernyataan negatif (unfavorable), yang akan dilakukan reverse coding pada proses input data (validitas item pernyataan pada nilai $0.526-0.861$ dengan nilai $r$ tabel 0.444, reabilitas item pada nilai 0.837 - 0.929 dengan konstanta 0.6) (Collis \& Messick, 2001).

Hasil belajar senam lantai hanya dinilai terbatas pada dua (2) aspek, yaitu aspek kognitif dan aspek psikomotor. Penilaian ranah kognitif (N1) menggunakan 20 soal pilihan ganda mengenai senam lantai yang dibagikan saat pretest dan post-test penelitian. Penilaian aspek psikomotor (N2) terdiri dari keterampilan gerakan berguling ke depan dan berguling ke belakang yang dinilai menggunakan lembar observasi. Pada tahap ini dilaksanakan kegiatan merancang instrumen dan perangkat pembelajaran meliputi rencana pelaksanaan pembelajaran (RPP dan tes hasil belajar peserta didik, yang selanjutkan dilakukan uji coba sebelum penelitian dimulai. Isi instrumen dan perangkat pembelajaran yang dirancang disesuaikan dengan kurikulum yang diterapkan di sekolah tempat penelitian dan model pembelajaran yang digunakan dalam penelitian. Data dianalisis menggunakan analisis deskriptif dan analisis kovarian (ANCOVA) dengan tingkat kepercayaan 95\% $(\alpha=0.05)$. Uji normalitas menggunakan uji Lilliefors, sedangkan uji homogenitas dalam penelitian ini menggunakan levene's test of equality of error variances. Tiga (3) jenis hipotesis yang diuji terdiri dari main effect, interaction effect, dan simple effect.

\section{HASIL DAN PEMBAHASAN}

\section{Hasil}

Hasil penelitian pengaruh model pembelajaran PBL dan minat belajar terhadap hasil belajar senam lantai di peserta didik kelas V di SD Negeri 3 Kampung Baru yang dilakukan pada tanggal 15 - 18 September 2020 dapat dijabarkan melalui paparan data lengkap mengenai hasil belajar senam lantai peserta didik yang diperoleh pada penelitian ini disajikan pada Tabel 1. Dalam penelitian ini, uji normalitas data diuji dan dianalisis dengan teknik uji Lilliefors menggunakan program Microsoft Excel 2019. Uji normalitas dengan menggunakan taraf signifikansi $\alpha=0,05$, dengan $n=20$, nilai $D_{\operatorname{tabel}(20)}=0.190$

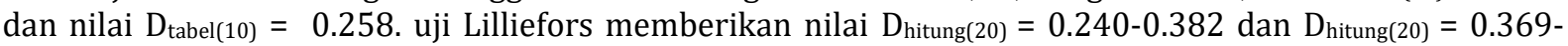
0.464, sehingga dapat disimpulkan data berdistribusi normal. Sedangkan uji homogenitas dengan uji levene's test of equality of error variances yang dilakukan didapatkan nilai sig. sebesar 0.140, sehingga sig. $>0.05$, dan dapat disimpulkan bahwa keseluruhan data bersifat homogen. Berdasarkan kedua uji prasyarat tersebut, analisis data dilanjutkan kepada uji hipotesis. Nilai statistik Uji-F pada Tabel 2, pada baris A terlihat bahwa nilai $\mathrm{F}_{\text {hitung }}=4.943$, lebih besar dari $\mathrm{F}_{\text {tabel }}=2,014$ sehingga $\mathrm{H}_{0}$ ditolak, yang berarti bahwa terdapat perbedaan hasil belajar senam lantai peserta didik antara peserta didik yang mengikuti 
model pembelajaran PBL dengan peserta didik yang mengikuti model pembelajaran konvensional. Temuan lain yang didapatkan dalam penelitian ini bahwa selisih rata-rata antara kelompok model pembelajaran konvensional mempunyai selisih skor 3.30 lebih tinggi daripada model pembelajaran PBL, yang peneliti menilai bahwa terdapat perbedaan yang tipis (pada Tabel 1).

Tabel 1. Rekapitulasi Hasil Perhitungan Skor Hasil Belajar Senam Lantai (N=40)

\begin{tabular}{ccccccccc}
\hline $\begin{array}{c}\text { Statistik } \\
\text { Kelompok }\end{array}$ & $\mathbf{n}$ & Mean & $\boldsymbol{S D}$ & Varians & Modus & Median & Min & Max \\
\hline $\mathbf{A}_{1}$ & 75,50 & 13,991 & 195,737 & 64 & 75 & 56 & 94 & 75,50 \\
$\mathbf{A}_{2}$ & 78,80 & 7,931 & 62,905 & 64 & 80 & 60 & 88 & 78,80 \\
$\mathbf{B}_{1}$ & 81,10 & 9,635 & 92,832 & 86 & 85 & 60 & 94 & 81,10 \\
$\mathbf{B}_{2}$ & 73,20 & 11,777 & 138,695 & 64 & 71 & 56 & 88 & 73,20 \\
$\mathbf{A}_{\mathbf{1}} \mathbf{B}_{1}$ & 88,80 & 3,293 & 10,844 & 86 & 89 & 84 & 94 & 88,80 \\
$\mathbf{A}_{\mathbf{1}} \mathbf{B}_{2}$ & 62,20 & 3,048 & 9,289 & 64 & 64 & 56 & 66 & 62,20 \\
$\mathbf{A}_{2} \mathbf{B}_{1}$ & 73,40 & 7,306 & 53,378 & 74 & 74 & 60 & 86 & 73,40 \\
$\mathbf{A}_{2} \mathbf{B}_{2}$ & 84,20 & 3,824 & 14,622 & 86 & 86 & 76 & 88 & 84,20 \\
\hline
\end{tabular}

Keterangan:

$\mathrm{A}_{1}=$ Model pembelajaran PBL; $\mathrm{A}_{2}=$ Model pembelajaran Konvensional; $\mathrm{B}_{1}=$ Minat belajar tinggi; $\mathrm{B}_{2}=$ Minat belajar rendah; $\mathrm{A}_{1} \mathrm{~B}_{1}=$ kelompok peserta didik yang mengikuti model pembelajaran PBL dengan minat belajar tinggi; $\mathrm{A}_{1} \mathrm{~B}_{2}=$ kelompok peserta didik yang mengikuti model pembelajaran PBL dengan minat belajar rendah; $\mathrm{A}_{2} \mathrm{~B}_{1}=$ kelompok peserta didik yang mengikuti model pembelajaran konvensional dengan minat belajar tinggi; $\mathrm{A}_{2} \mathrm{~B}_{2}=$ kelompok peserta didik yang mengikuti model pembelajaran konvensional dengan minat belajar tinggi.

Tabel 2. Statistik uji-F tentang A dan A*B Terhadap Hasil Belajar Senam Lantai Peserta didik

\begin{tabular}{|c|c|c|c|c|c|c|c|}
\hline $\begin{array}{c}\text { Sumber } \\
\text { Varian }\end{array}$ & JK & $\mathbf{d b}$ & RJK & $\mathbf{F}_{\mathbf{h}}$ & Sig. & $F_{\text {tabel }}$ & Ket \\
\hline Corrected Model & $4229,900^{a}$ & 3 & 1409,967 & 63,992 & 0,000 & & \\
\hline Intercept & 238084,900 & 1 & 238084,900 & 10805,669 & 0,000 & & \\
\hline A & 108,900 & 1 & 108,900 & 4,943 & 0,033 & 2,014 & Sig. \\
\hline B & 624,100 & 1 & 624,100 & 28,325 & 0,000 & & \\
\hline$A^{*} B$ & 3496,900 & 1 & 3496,900 & 158,710 & 0,000 & 2,014 & Sig. \\
\hline Error & 793,200 & 36 & 22,033 & & & & \\
\hline Total & 243108,000 & 40 & & & & & \\
\hline Corrected Total & 5023,100 & 39 & & & & & \\
\hline
\end{tabular}

Keterangan: JK = Jumlah kuadrat; db = Derajat kebebasan; RJK = Rata-rata jumlah kuadrat

Hasil analisis menunjukkan bahwa nilai statistik Uji-F di atas pada Tabel 2, baris kelompok*minat belajar diperoleh nilai $F_{\text {hitung }}=158.710$, sehingga lebih besar dari $F_{\text {tabel }}=2,014$ pada taraf signifikansi $\alpha=$ 0,05. Sehingga $\mathrm{H}_{0}$ ditolak yang berarti pengaruh model pembelajaran terhadap hasil belajar senam lantai bergantung pada minat belajar. Artinya, adanya pengaruh interaksi antara model pembelajaran dan minat belajar terhadap hasil belajar senam lantai peserta didik. Berdasarkan hasil uji $t$-scheffe, peserta didik pada peserta didik yang belajar menggunakan model pembelajaran PBL pada peserta didik yang memiliki minat belajar rendah $\left(\mathrm{A}_{1} \mathrm{~B}_{2}\right)$ memiliki rata-rata hasil belajar senam lantai sebesar 62.20 dengan simpangan baku 3.048, sedangkan peserta didik yang belajar menggunakan model pembelajaran konvensional pada peserta didik yang memiliki minat belajar rendah $\left(\mathrm{A}_{2} \mathrm{~B}_{2}\right)$ memiliki rata-rata hasil belajar senam lantai sebesar 84.20 dengan simpangan baku 3.824, dan nilai RJKdalam sebesar 22.033. Hasil analisis pengujian pada tabel 4.15 menunjukkan bahwa nilai statistik uji-t diperoleh nilai $t_{\text {hitung }}=14,227$ lebih besar dari $t_{\text {tabel }}\left(t_{\text {tabel(20) }}=1.7247\right.$ pada taraf signifikansi $\left.\alpha=0.05\right)$, sehingga $H_{o}$ ditolak maka dapat disimpulkan bahwa untuk peserta didik yang memiliki minat belajar rendah. Hasil belajar senam lantai peserta didik yang belajar menggunakan model pembelajaran konvensional lebih baik dibandingkan dengan peserta didik yang belajar menggunakan model pembelajaran PBL. 
Tabel 3. Perbedaan Hasil Belajar Senam Lantai Peserta didik Berdasarkan Perbedaan Minat Belajar dan Model Pembelajaran

\begin{tabular}{|c|c|c|c|c|c|}
\hline $\begin{array}{l}\text { Minat } \\
\text { Belajar }\end{array}$ & $\begin{array}{c}\text { Model } \\
\text { Pembelajaran }\end{array}$ & $\begin{array}{c}\text { Model } \\
\text { Pembelajaran } \\
\text { PBL } \\
\end{array}$ & $\begin{array}{c}\text { Model } \\
\text { Pembelajaran } \\
\text { Konvensional } \\
\end{array}$ & $\mathbf{t}_{\text {hitung }}$ & $\begin{array}{c}t_{\text {tabel }} \\
(\alpha=0,05)\end{array}$ \\
\hline \multirow{3}{*}{ Tinggi } & Rata-rata & 88,80 & 73,40 & & \\
\hline & $\begin{array}{l}\text { RJK dalam } \\
\mathrm{db}\end{array}$ & \multicolumn{2}{|c|}{$\begin{array}{c}22,033 \\
20\end{array}$} & 6,077 & 1,7247 \\
\hline & Rata-rata & 62,20 & 84,20 & & \\
\hline Rendah & $\begin{array}{l}\text { RJK dalam } \\
\mathrm{db}\end{array}$ & \multicolumn{2}{|c|}{$\begin{array}{c}22,033 \\
20\end{array}$} & 84,20 & 14,227 \\
\hline
\end{tabular}

Berdasarkan hasil analisis, adanya pengaruh model pembelajaran PBL dan minat belajar terhadap hasil belajar senam lantai peserta didik kelas V di SD Negeri 3 Kampung Baru disebabkan oleh beberapa faktor. Pertama, model pembelajaran Problem Based Learning dapat membantu siswa dalam belajar. Proses pembelajaran menggunakan Problem Based Learning memberikan siswa kesempatan untuk bertanya apabila mengalami kesulitan terkait materi yang disampaikan. Kegiatan pembelajaran yang mengaktifkan siswa dapat mempermudah siswa dalam mengikuti pembelajaran (A.Montepara et al., 2021; Dwi et al., 2013; Hussin et al., 2018). Peningkatan hasil belajar siswa melalui PBL dalam pembelajaran senam lantai dengan langkah-langkah: a) menyimak masalah dalam pelaksanaan senam lantai, b) menganalisis masalah, c) mengajukan pertanyaan mengenai masalah senam lantai, d) mengamati gerakan senam lantai, dan e) mempraktikkan senam lantai denga teknik yang tepat. Model pembelajaran berbasis masalah ini membuat siswa lebih aktif, kreatif, dan inovatif dalam upaya meningkatkan kemampuan memecahkan masalah, sehingga hasil belajar siswa dapat meningkat .Kedua, penerapan model pembelajaran lebih banyak melibatkan keaktifan peserta didik dibandingkan keaktifan guru, memberikan pujian atau penghargaan kepada peserta didik yang mampu memperoleh hasil belajar yang tinggi. Hal tersebut dapat meningkatkan minat belajar siswa. Minat belajar berfungsi untuk merangsang peserta didik untuk semangat belajar. Minat pada dasarnya merupakan perhatian yang bersifat khusus (Setiawati et al., 2020). Peserta didik yang menaruh minat pada suatu mata pelajaran, perhatiannya akan tinggi dan minatnya berfungsi sebagai pendorong kuat untuk terlibat secara aktif dalam kegiatan belajar mengajar (Hakim, 2009: 38). Apabila peserta didik memiliki minat terhadap sesuatu, maka peserta didik tersebut cenderung untuk memberi perhatian yang lebih besar terhadap sesuatu yang diminatinya dan mengikuti kegiatan yang dilakukan dengan rasa senang. Peserta didik yang berminat terhadap olahraga tentunya akan dengan sungguh-sungguh mengikuti pembelajaran olahraga yang diberikan. Mereka merasa senang dengan adanya penyajian pelajaran olahraga. Peserta didik yang mempunyai minat terhadap suatu objek atau aktivitas, berarti telah menetapkan tujuan yang berguna bagi dirinya ,sehingga peserta didik akan cenderung untuk menyukainya.

Temuan ini diperkuat dengan temuan sebelumnya yang menyatakan model pembelajaran PBL mempunyai pengaruh yang signifikan terhadap hasil belajar roll peserta didik pada mata pelajaran PJOK (Wahyudi \& Hartati, 2015). Model pembelajaran PBL dengan lembar kerja peserta didik dapat membantu meningkatkan aktivitas dan hasil belajar peserta didik (Afifah et al., 2019; Kristiana \& Radia, 2021; I. B. Prasetyo, 2018; Rani \& Syukur, 2019). Model PBL berbasis eksperimen berpengaruh signifikan terhadap hasil belajar kognitif dan afektif siswa (Khoiri et al., 2020). Peserta didik dengan minat belajar tinggi, hasil belajar IPS lebih tinggi menggunakan model pembelajaran PBL daripada model pembelajaran STAD. Hal tersebut dikarenakan peserta didik dengan minat belajar tinggi memiliki ketertarikan dalam proses kegiatan pembelajaran, perhatian yang penuh terhadap materi pelajaran, berpartisipasi aktif dalam kegiatan pembelajaran, bertanggung jawab terhadap tugas, mampu memberikan dorongan positif kepada teman-temannya, dan menimbulkan minat belajar yang tinggi (Sadiyah, 2018). Berdasarkan hal tersebut berarti model pembelajaran PBL efektif untuk meningkatkan hasil belajar dan minat belajar peserta didik. Model pembelajaran PBL memberikan peluang lebih kepada peserta didik untuk mencapai hasil belajar yang lebih optimal dibandingkan dengan model pembelajaran konvensional pada peserta didik dengan minat belajar tinggi. Implikasi penelitian ini berdampak pada terciptanya suasana belajar yang menyenangkan. Hal ini membuat siswa terlibat penuh dalam belajar serta dapat meningkatkan sikap kerjasama antarsiswa, sehingga berpengaruh pada hasil belajar dan minat siswa yang meningkat.

\section{SIMPULAN}

Berdasarkan hasil analisis dapat disimpulkan bahwa model pembelajaran PBL memberikan pengaruh positif terhadap hasil belajar dan minat peserta didik kelas V SDN 3 Kampung Baru. Peserta 
didik belajar dengan model PBL mempunyai hasil belajar senam lantai lebih tinggi daripada peserta didik yang menggunakan model pembelajaran konvensional. Penelitian ini diharapkan dapat dijadikan sebagai salah satu refrensi dalam penyelesaian masalah pembelajaran Olah Raga khususnya senam lantai di Sekolah Dasar.

\section{DAFTAR PUSTAKA}

A.Montepara, C., G.Woods, A., \& W.Wolfgang, K. (2021). Problem-Based Learning Case Studies: Delivery of an Educational Method and Perceptions at Two Schools of Pharmacy in Italy. Currents in Pharmacy Teaching and Learning, 6, 717-722. https://doi.org/10.1016/j.cptl.2021.01.026.

Afifah, E. P., Wahyudi, \& Setiawan, Y. (2019). Efektivitas Problem Based Learning dan Problem Solving terhadap Kemampuan Berpikir Kritis Siswa Kelas V dalam Pembelajaran Matematika. Journal of Mathematics Education, Science and Technology, 4(1), 95-107. https: //doi.org/10.30651/must.v4i1.2822.

Awe, E. Y., \& Benge, K. (2017). Hubungan Antara Minat dan Motivasi Belajar dengan Hasil Belajar IPA pada Siswa SD. Journal of Education Technology, 1(4), 231. https://doi.org/10.23887/jet.v1i4.12859.

Bukhari, K., Efendi, Z. M., \& Jama, J. (2019). The Development of Physical and Sport Education Learning Model by Using Small Games. Journal of Physics: Conference Series, 1387(1). https://doi.org/10.1088/1742-6596/1387/1/012014.

Cahyo, R. N., Wasitohadi, W., \& Rahayu, T. S. (2018). Upaya Meningkatkan Hasil Belajar IPS melalui Model Problem Based Learning (PBL) Berbantuan Media Audio Visual pada Siswa Kelas 4 SD. Jurnal Basicedu, 2(1), 28-32. https://doi.org/10.31004/basicedu.v3i1.70.

Collis, J. M., \& Messick, S. (2001). Intelligence and Personality: Bridging the Gap in Theory and Measurement. Lawrence Erlbraum Associates.

Dakabesi, D., Supiah, I., \& Luoise, Y. (2019). The Effect of Problem Based Learning Model on Critical Thinking Skills in the Context of Chemical Reaction Rate. Journal of Education and Learning (EduLearn), 13(3), 395-401. https://doi.org/10.11591/edulearn.v13i3.13887.

Diah Purwati, N. L. P., Wibawa, I. M. C., \& Margunayasa, I. G. (2019). Pengaruh Numbered Head Together Berbantuan Gambar terhadap Penguasaan Kompetensi Pengetahuan IPA. Jurnal Pedagogi Dan Pembelajaran, 2(3), 282. https://doi.org/10.23887/jp2.v2i3.19275.

Dwi, Arif, \& Sentot. (2013). Pengaruh Strategi Problem Based Learning Berbasis ICT Terhadap Pemecahan Konsep dan Kemampuan Pemecahan Masalah Fisika. Jurnal Pendidikan Fisika Indonesia, 9(1). https://doi.org/10.15294/jpfi.v9i1.2575.

Hakim, L. (2009). Perencanaan Pembelajaran. CV. Wacana Prima.

Halilaj, B., Madić, D., \& Sporiš, G. (2018). Gymnastics Skill Level and Fitness in Students Selected for Physical Education Programs. Croatian Journal of Education, 20(3), 825-841. https://doi.org/10.15516/cje.v20i3.2985.

Hidayat, A. (2017). Peningkatan Aktivitas Gerak Lokomotor, Nonlokomotor, dan Manipulatif Menggunakan Model Permainan pada Siswa Sekolah Dasar. Jurnal Pendidikan Jasmani Dan Olahraga, 2(2), 21. https://doi.org/10.17509/jpjo.v2i2.8175.

Hussin, W. N. T. W., Harun, J., \& Shukor, N. A. (2018). Problem Based Learning to Enhance Students Critical Thinking Skill via Online Tools. Asian Social Science, 15(1), 14. https://doi.org/10.5539/ass.v15n1p14.

Indra, R. C., Hartanto, P. D., Kusumaningtyas, D. A., Ali, R. M., \& Muchlas. (2021). Community Radio-Based Blended Learning Model: A Promising Learning Model in Remote Area during Pandemic Era. Heliyon, 7(7). https://doi.org/10.1016/j.heliyon.2021.e07511.

Kaban, R. H., Anzelina, D., Sinaga, R., \& Silaban, P. J. (2021). Pengaruh Model Pembelajaran PAKEM terhadap Hasil Belajar Siswa di Sekolah Dasar. Jurnal Basicedu, 5(1), 102-109. https://doi.org/10.31004/basicedu.v5i1.574.

Khoiri, N., Huda, C., \& Wiyanto, W. (2020). Building Cognitive and Affective Learning Outcomes on the Concept of Linear Motion through Ticker Timer Experiment Using Problem Based Learning. Jurnal Penelitian Dan Pembelajaran IPA, 6(2), $268 \quad$ - 282. https://doi.org/10.30870/jppi.v6i2.9006.

Khoiruzzadim, Barokahm, \& Kamilaa. (2020). Upaya Guru dalam Memaksimalkan Perkembangan Kognitif, Sosial dan Motorik Anak Usia Dini. JECED : Journal of Early Childhood Education and Development, 2(1), 40-51. https://doi.org/10.15642/jeced.v2i1.561.

Kristiana, T. F., \& Radia, E. H. (2021). Meta Analisis Penerapan Model Problem Based Learning dalam Meningkatkan Hasil Belajar IPA Siswa Sekolah Dasar. Jurnal Basicedu, 5(2), 818-826. https://doi.org/10.31004/basicedu.v5i2.828. 
Laksono, Y. S., Ariyanti, G., \& Santoso, F. G. I. (2016). Hubungan Minat Belajar Siswa terhadap Prestasi Belajar Matematika Siswa dalam Pembelajaran Kooperatif Tipe Stad Menggunakan Komik. Jurnal Edukasi Matematika Dan Sains, 1(2), 60-64. https://doi.org/10.25273/jems.v1i2.143.

Lengo, M. D., \& Djam, J. J. A. (2019). Jurnal Inspirasi Pendidikan. Jurnal Inspirasi Pendidikan, 9(2), 85-94. https://doi.org/10.21831.

Lestari, K. R. (2013). Model Pembelajaran Koperatif STAD untuk Meningkatkan Aktivitas dan Hasil Belajar Senam Lantai. Jurnal Pendidikan Jasmani, Olahraga, Dan Kesehatan Undiksha, 1(1), 1-10. https: //ejournal.undiksha.ac.id/index.php/JJP/article/view/333.

Maman, M., \& Rajab, A. A. (2016). The Implementation of Cooperative Learning Model 'Number Heads Together (NHT)' in Improving the Students' Ability in Reading Comprehension. International Journal of Evaluation and Research in Education (IJERE), 5(2), 174-180. https://doi.org/10.11591/ijere.v5i2.4536.

Mashud, M. (2020). The Effectiveness of Physical Education Learning in Elementary School Located in Wetland Environment. Jurnal Pendidikan: Teori, Penelitian, Dan Pengembangan, 5(2), 265-270. https://doi.org/10.17977/jptpp.v5i2.13194.

Masithoh, D. (2018). Teachers' Scientific Approach Implementation in Inculcating the Students' Scientific Attitudes. Jurnal Prima Edukasia, 32-43. https://doi.org/10.21831/jpe.v6i1.14282.

Misla, M., \& Mawardi, M. (2020). Efektifitas PBL dan Problem Solving Siswa SD Ditinjau dari Kemampuan Berpikir Kritis. Jurnal Ilmiah Sekolah Dasar, 4(1), 60. https://doi.org/10.23887/jisd.v4i1.24279.

Muhajir. (2014). Buku Guru Pendidikan Jasmani Olahraga dan Kesehatan Kelas VII. Pusat Kurikulum dan Perbukuan, Balitbang, Kemendikbud.

Nuryanto, A., \& Resita, C. (2019). Minat Belajar Siswa Dalam Pembelajaran Senam Lantai Loncat Kangkang pada Siswa Kelas X MA Negeri 2 Karawang. JSPEED, 2(1), 1-7. https: //journal.unsika.ac.id/index.php/speed/article/view/2219/1715.

Prasetyo, I. B. (2018). Penerapan Model Problem Based Learning (PBL) untuk Meningkatkan Proses dan Hasil Belajar Muatan PPKn pada Tema 8 Subtema 1. Jurnal Penelitian Dan Pengembangan Pendidikan, 2(2), 279-285. https://doi.org/10.23887/jppp.v2i2.15465.

Prasetyo, I. D., \& Sunarti. (2016). Meningkatkan Kemampuan Senam Lantai Guling Belakang Melalui Media Video. Meningkatkan Kemampuan Senam Lantai Guling Belakang Melalui Media Video, 12(1), 510. https://journal.uny.ac.id/index.php/jpji/article/download/10210/7931.

Rahmayani, A., Siswanto, J., \& Arief Budiman, M. (2019). Pengaruh Model Pembelajaran Discovery Learning dengan Menggunakan Mediavideo terhadap Hasil Belajar. Jurnal Ilmiah Sekolah Dasar. https://doi.org/10.23887/jisd.v3i2.18055.

Rani, A. R., \& Syukur, Y. (2019). Pengembangan Lembaran Kerja Peserta Didik dengan Model Problem Based Learning pada Siswa Kelas IV Sekolah Dasar. Jurna Basicedu, 3(2), 674 - 680. https://doi.org/10.31004/basicedu.v3i2.54.

Rosalina, L., \& Junaidi, J. (2020). Hubungan Minat Belajar dengan Hasil Belajar pada Pembelajaran Sosiologi Pada Kelas XII IPS di SMAN 5 Padang. Jurnal Sikola: Jurnal Kajian Pendidikan Dan Pembelajaran, 1(3), 175-181. https://doi.org/10.24036/sikola.v1i3.24.

Sadiyah, H. (2018). Pengaruh Penggunaan Model Pembelajaran Jigsaw dan STAD Minat Belajar terhadap Hasil Belajar IPS Kelas VI Sekolah Dasar Gugus V Citeureup - Bogor Jawa Barat. Universitas Terbuka.

Saputro, O. A., \& Rayahu, T. S. (2020). Perbedaan Pengaruh Penerapan Model Pembelajaran Project Based Learning ( PjBL ) dan Problem Based Learning ( PBL ) Berbantuan Media Monopoli. Jurnal Imiah Pendidikan Dan Pembelajaran, 4(1), 185-193. https://doi.org/10.23887/jipp.v4i1.24719.

Saraswatha, I. M. D., Japa, I. G. N., \& Wibawa, I. M. C. (2016). Penerapan Model PBL untuk Meningkatkan Minat dan Hasil Belajar IPS pada Siswa Kelas IV. Mimbar PGSD Undiksha, 4(1). https://doi.org/10.23887/jjpgsd.v4i1.7015.

Sartika, R. P. (2018). Implementasi Model Problem Based Learning dalam Meningkatkan Pemahaman Konsep Mahasiswa pada Mata Kuliah Manajemen Laboratorium. EDUSAINS, 10(2), 197-205. https://doi.org/10.15408/es.v10i2.7376.

Schiefele, U. (1999). Scientific Studies of Reading Interest and Learning From Text. Scientific Studies of Reading, 3(February 2015), 199-205. https://doi.org/10.1207/s1532799xssr0303.

Setiawati, K. S., Parwata, I. G. L. A., \& Suratmin. (2020). Pengaruh Model Pembelajaran dan Minat Belajar terhadap Hasil Belajar Senam Lantai. Jurnal PENJAKORA, 7(1), 17-29. https://doi.org/10.23887/penjakora.v7i1.24444.

Stephani, M. R. (2017). Stimulasi Kemampuan Berpikir Kritis Melalui Pembelajaran Berbasis Masalah pada Pendidikan Jasmani. Jurnal Pendidikan Jasmani Dan Olahraga, 2(1), 16-27. https://doi.org/10.17509/jpjo.v2i1.6397. 
Steven RTerrell Ph D. (2014). Introduction to the Special Section of the Internet in Higher Education: The American Educational Research Association's Online Teaching and Learning Special Interest Group. The Internet and Higher Education, 21, 59. https://doi.org/10.1016/j.iheduc.2014.01.001.

Syahrul, \& Nurhafizah. (2021). Analisis Pengaruh Pola Asuh Orang Tua terhadap Perkembangan Sosial dan Emosional Anak Usia Dini di masa Pandemi Corona Virus 19. Jurnal Basicedu, 5(2), 683-696. https: //doi.org/10.31004/basicedu.v5i2.792.

Wahyudi, N., \& Hartati, S. C. Y. (2015). Penerapan Model Pembelajaran Berbasis Masalah terhadap Hasil Belajar Roll Depan Kaki Tekuk dalam Pembelajaran Pendidikan Jasmani, Olahraga, dan Kesehatan. Jurnal Pendidikan Olahraga Dan Kesehatan, 3(2), 380-386.

Wardani, W. F. (2018). Penerapan Model Problem Based Learning (PBL) untuk Meningkatkan Hasil Belajar Siswa pada Mata Pelajaran IPS Kelas IV MI Islamiyah Sumberrejo Batanghari Tahun Pelajaran 2017/2018. http://repository.metrouniv.ac.id/id/eprint/2111.

Wati, A. K., \& Muhsin. (2019). Pengaruh Minat Belajar, Motivasi Belajar, Lingkungan Keluarga, dan Lingkungan Sekolah terhadap Kesulitan Belajar. Economic Education Analysis Journal, 8(2), 797813. https://doi.org/10.15294/eeaj.v8i2.31517.

Wicaksono, P. N., Kusuma, I. J., Festiawan, R., Widanita, N., \& Anggraeni, D. (2020). Evaluasi Penerapan Pendekatan Saintifik pada Pembelajaran Pendidikan Jasmani Materi Teknik Dasar Passing Sepak Bola. Jurnal Pendidikan Jasmani Indonesia, 16(1), 41-54. https://doi.org/10.21831/jpji.v16i1.29774.

Widoretno, S., \& Dwiastuti, S. (2019). Improving Students' Thinking Skill Based on Class Interaction in Discovery Instructional: A Case of Lesson Study. Jurnal Pendidikan IPA Indonesia, 8(3), 347-353. https://doi.org/10.15294/jpii.v8i3.20003.

Wisnu Budi Wijaya, I. K. (2019). Menanamkan Konsep Catur Paramita pada Anak Usia Dini di Lingkungan Keluarga Dan Sekolah. Pratama Widya: Jurnal Pendidikan Anak Usia Dini, 3(2), 41-46. https://doi.org/10.25078/pw.v3i2.737. 